\title{
Inoculation with Azospirillum, associated with nitrogen fertilization in maize ${ }^{1}$
}

\author{
Maria do Carmo Lana ${ }^{2 *}$, Janaína Dartora ${ }^{3}$, Deniele Marini ${ }^{3}$, João Elias Hann ${ }^{4}$
}

\begin{abstract}
The biological nitrogen fixation is an alternative to supply the nitrogen needed for maize. The objective of this study was to evaluate the development and yield of maize in response to inoculation with Azospirillum associated with nitrogen fertilization. We conducted two field experiments in the summer harvest, the first in the 2000/2001 crop year in the region of Marechal Cândido Rondon, under conventional tillage, and second in the 2002/2003 agricultural year in the region of Cascavel, under no tillage. The experimental design in both experiments was a randomized complete block, with four replications, 2x2x2 factorial, with two levels of nitrogen at sowing (zero and $20 \mathrm{~kg} \mathrm{ha}^{-1}$ ), two levels of inoculum (zero and $200 \mathrm{~g} \mathrm{ha}^{-1}$ ) and two levels of nitrogen in topdressing (zero and $100 \mathrm{~kg} \mathrm{ha}^{-1}$ ). There was evaluated the height of ear insertion, total plant height, leaf $\mathrm{N}$ content, shoot dry biomass and grain yield. The height of ear insertion and total plant height were not influenced by the factors under study. Nitrogen fertilization at sowing increased the leaf $\mathrm{N}$ content, causing the opposite effect when combined with inoculation. Inoculation with Azospirillum in the absence of nitrogen, provide productivity increases of 15.4\% and 7.4\% for 2000/2001 and 2002/2003 crops, respectively. The inoculation provided productivity similar to that obtained with $100 \mathrm{~kg} \mathrm{ha}^{-1}$ in topdressing in crop 2000/2001, while in association with the topdressing, reduced productivity and shoot dry biomass in crop 2002/2003.
\end{abstract}

Key words: Zea mays L., biological nitrogen fixation, leaf nitrogen content.

\section{RESUMO}

\section{Inoculação com Azospirillum, associada à adubação nitrogenada, na cultura do milho}

A fixação biológica de nitrogênio é uma alternativa para o suprimento de parte do nitrogênio necessário à cultura do milho. Com o objetivo de avaliar o desenvolvimento e produtividade do milho, em resposta à inoculação com Azospirillum brasilense, associada à adubação nitrogenada, foram conduzidos dois experimentos na safra de verão, o primeiro, no ano agrícola 2000/2001, no município de Marechal Cândido Rondon, sob plantio convencional, e, o segundo, no ano agrícola 2002/2003, no município de Cascavel, sob plantio direto. O delineamento experimental empregado foi em blocos casualizados, com quatro repetições, esquema fatorial 2x2x2, sendo dois níveis de adubação nitrogenada na semeadura (0 e $20 \mathrm{~kg} \mathrm{ha}^{-1}$ ); dois níveis de inoculante (0 e $200 \mathrm{~g} \mathrm{ha}^{-1}$ ) e dois níveis de nitrogênio em cobertura (0 e $100 \mathrm{~kg}$ $\mathrm{ha}^{-1}$ ). Avaliaram-se altura de inserção da espiga, altura total das plantas, teor de nitrogênio foliar, biomassa seca de parte aérea e produtividade de grãos. As alturas de inserção da espiga e total das plantas não foram influenciadas pelos fatores em estudo. A adubação nitrogenada de base proporcionou incremento no teor de nitrogênio foliar, provocando efeito inverso, quando associada à inoculação. A inoculação com Azospirillum, na ausência de adubação nitrogenada,

Recebido para publicação em 20/09/2011 e aprovado em 19/04/2012

${ }^{1}$ Part of research conducted by the last author to obtain the Agronomist Engineer degree at the Universidade Estadual do Oeste do Paraná - UNIOESTE.

${ }^{2}$ Agronomist Engineer, Doctor Science. Universidade Estadual do Oeste do Paraná - UNIOESTE, Rua Pernambuco, 1777, Caixa Postal 91, 85960-000, Marechal Cândido Rondon, Paraná, Brazil. maria.lana@unioeste.br (*corresponding author)

${ }_{3}^{3}$ Agronomist Engineer Master Science, Universidade Estadual do Oeste do Paraná - UNIOESTE, Rua Pernambuco, 1777, Caixa Postal 91, 85960-000, Marechal Cândido Rondon, Paraná, Brazil. janaina_dartora@yahoo.com.br; denielemarini@yahoo.com.br

${ }^{4}$ Agronomist Engineer, Agropontes Consultoria e Planejamento Agrícola, Avenida Presidente Epitácio, 558, 85940-000, Quatro Pontes, Paraná, Brazil. joaoeliashahn@bol.com.br 
proporcionou incrementos na produtividade de 15,4 e 7,4\%, para as safras 2000/2001 e 2002/2003, respectivamente. A inoculação proporcionou produtividade semelhante àquela obtida com $100 \mathrm{~kg} \mathrm{ha}^{-1} \mathrm{de} \mathrm{N}$ em cobertura, na safra 2000/ 2001, enquanto, em associação com a adubação em cobertura, reduziu a produtividade e a biomassa seca de parte aérea na safra 2002/2003.

Palavras-chave: Zea mays L., fixação biológica de nitrogênio, teor de nitrogênio foliar.

\section{INTRODUCTION}

Maize (Zea mays L.) is one of the most cultivated crops in the world, and it is usually affected by problems of environmental stress, among which we may highlight low soil fertility, which, most of the times, has nitrogen deficiency.

Nitrogen is considered the mineral element that plants need in the greatest amount (Taiz \& Zeiger, 2004), and it is important both to increase grain production and to rise protein content. Considering as well that cereals account for the production of most part of the food consumed by humans, clearly even if only part of nitrogen was provided by the association with fixing bacteria, nitrogen fertilizer would still be considerably economic (Döbereiner, 1992). Therefore, biological nitrogen fixation is an alternative to supply part of the nitrogen needed for maize culture.

Inoculation of Azospirillum spp. bacteria in grasses has caused significant increases in root growth, resulting in better benefit and use of fertilizer and water and, consequently, better plant growth (Baldani et al., 1997). According to Okon \& Vanderleyden (1997) at least part or, perhaps many of these effects caused by Azospirillum spp. on plants may be associated with the bacteria production of growth enhancing substances, including auxin, cytokinins and gibberellins, and not only the fixation of nitrogen.

Several authors have reported the positive effects of the interaction between Azospirillum spp. and maize, such as increases in dry matter production, grain yield and nitrogen accumulation in inoculated plants, mainly when unimproved genotypes were involved in the presence of low nitrogen availability (Okon \& Vanderleyden, 1997; Hungria et al., 2010).

There is also a wide variety of results in the literature regarding the relationship between inoculation and nitrogen fertilization. Barros Neto (2008), when working with maize subjected to nitrogen fertilization levels (100 and $150 \mathrm{~kg} \mathrm{ha}^{-1}$ of N) and inoculation of product based on A. brasilense, have found that inoculation provided an increase of $793 \mathrm{~kg} \mathrm{ha}^{-1}$ in grain yield compared to control. Reis Júnior et al. (2008) observed an increase in dry matter of maize roots inoculated with Azospirillum spp. and associated this higher yield in dry mass of inoculated plants with the production of growth enhancing substances by bacteria. In the same way, Quadros (2009) have found increases of up to $3770 \mathrm{~kg} \mathrm{ha}^{-1}$ on the yield of dry weight of maize shoots, when seeds were inoculated with A. brasilense in relation to control.

Further studies on the interaction of nitrogen fertilization and its influence on the development of maize culture under inoculation with Azospirillum spp. are necessary. Thus, the objective of this work was to evaluate the development and yield of maize in response to inoculation with Azospirillum spp. associated with nitrogen fertilization, at sowing and at top dressing.

\section{MATERIAL AND METHODS}

Two experiments were conducted in the field on the summer harvest. The first in the agricultural year 2000/ 2001 in conventional tillage, with the BR 205 hybrid developed by Embrapa, in the region of Marechal Cândido Rondon. And the second in the agricultural year 2002/ 2003 in no-tillage system with the hybrid AG 6018 YG of Agroceres in the region of Cascavel, both in the western region of Paraná state, Brazil, in an eutroferric Oxisol with chemical characteristics that are shown on Table 1.

The experimental design used in both experiments was that of randomized blocks, with four replicates and treatments arranged in a 2x2x2 factorial scheme, with two levels of nitrogen fertilizer at sowing ( 0 and $20 \mathrm{~kg} \mathrm{ha}^{-1}$ of $\mathrm{N}$ ) in the form of ammonium sulfate, two levels of liquid inoculant AZ39 - Azospirillum brasilense (0 and $200 \mathrm{~g}$ ha' $\left.{ }^{1}\right)$ and two levels of nitrogen in topdressing ( 0 and $100 \mathrm{~kg}$ $\left.h^{-1}\right)$, supplied as urea $(45 \% \mathrm{~N})$. Inoculation was performed by dissolving the inoculum in a solution containing 25\% glucose mixed with the seeds and then made to sowing.

The application of nitrogen at sowing was made in furrow, and at topdressing, there was a broadcasting application at 35 days after plant emergence, at which time the plants had 4-6 leaves. Fertilization with phosphorus and potassium was carried out in the planting furrow according to the chemical analysis of soils. There were used triple superphosphate and potassium chloride, as fertilizer sources, applied at doses of $100 \mathrm{~kg} \mathrm{ha}^{-1}$ of $\mathrm{P}_{2} \mathrm{O}_{5}$ and $20 \mathrm{~kg} \mathrm{ha}^{-1}$ de $\mathrm{K}_{2} \mathrm{O}$ in the experiment conducted in Marechal Cândido Rondon, while in the experiment carried out in Cascavel, were applied $120 \mathrm{~kg} \mathrm{ha}^{-1}$ of $\mathrm{P}_{2} \mathrm{O}_{5}$ and $60 \mathrm{~kg}$ ha $^{-1}$ of $\mathrm{K}_{2} \mathrm{O}$ respectively. 
Each experimental plot consisted of four rows spaced by $0.9 \mathrm{~m}$ and with $6 \mathrm{~m}$ length. To obtain the usable area, the two side lines and $0.5 \mathrm{~m}$ from each end of the plot were eliminated, totaling $9 \mathrm{~m}^{2}$ per plot. The parameters assessed included: ear insertion height, plant total height, leaf $\mathrm{N}$ content, dry biomass production of shoots and grain yield.

In the assessment of ear insertion height and plant total height on the plot usable area, measurements were taken from the soil surface to the insertion of the ear and by the end of the stalk, respectively. In order to do so, a measurement ruler was used for surveying.

Leaf $\mathrm{N}$ content was determined using the method described by Tedesco et al. (1995), who recommends pick leaves of 10 plants per plot, at the stage of flowering of the culture, selecting the leaves in the opposite position and below the insertion of the ear.

Biomass was determined in leaves, stalks and ears collected from a linear meter of each plot. Before to be weighed the samples were dried in a forced circulation oven at $65^{\circ} \mathrm{C}$ to constant weight. Based on the mean moisture content of the sample, the dry biomass produced in each plot was calculated, then extrapolating to $\mathrm{kg} \mathrm{ha}^{-1}$.

To estimate the grain yield of the culture, all ears from the usable area of each plot were collected, and then threshing was performed with the aid of a manual thresher. The grains were exposed to the sun until they reached equilibrium moisture content (between 12 and 14\%), and then grain yield in $\mathrm{kg} \mathrm{ha}^{-1}$ was determined.

Results were subjected to analysis of variance, applying the $\mathrm{F}$ test at $5 \%$ probability. Means were compared by Tukey test at $5 \%$ probability.

\section{RESULTS AND DISCUSSION}

Plant height and ear insertion height were not modified by $\mathrm{N}$ fertilization and inoculation at both sites (Table 2), which can be attributed to genetic characteristics of each hybrid, a result also found by Campos et al.(2000) when working with the application of the Azospirillum spp. based Graminante inoculant and nitrogen applications in sowing and topdressing in maize culture.
For the experiment conducted in Marechal Cândido Rondon, there was a significant effect of the interaction between nitrogen topdressing fertilization and inoculation on productivity. The shoot dry biomass was significantly influenced by the interactions between nitrogen topdressing fertilization and inoculation, as well as between nitrogen fertilization of base and topdressing (Table 2).

The unfolding of the interaction between nitrogen topdressing fertilization and inoculation on yield and dry biomass of shoots in Marechal Cândido Rondon is shown on Table 3. It was found that, both for shoot dry biomass and for yield, the inoculation with Azospirillum spp. provided similar means for the treatments with and without nitrogen topdressing fertilization, suggesting the possibility of replacement of nitrogen topdressing fertilization by the use of inoculation. Considering that nitrogen fertilizers represent about $40 \%$ of total production costs of maize (Machado et al., 1998), such replacement would allow considerable savings in production costs.

It can also be noted on Table 3 that without the application of nitrogen topdressing fertilization, seed inoculation with Azospirillum significantly increased the production of shoot dry biomass in $652.3 \mathrm{~kg} \mathrm{ha}^{-1}$ and productivity in $891.9 \mathrm{~kg} \mathrm{ha}^{-1}$, with increases from 7.2 to $15.4 \%$ for these variables, respectively. These results exceed those obtained by Cavallet et al. (2000), who worked with the inoculation of maize seeds with a commercial product based on Azospirillum spp., and found an increase of $357 \mathrm{~kg} \mathrm{ha}^{-1}$ in productivity. Despite the increase provided by the inoculation, yield values obtained in this experiment were lower than the productivity of hybrid BR 205 which is $8700 \mathrm{~kg} \mathrm{ha}^{-1}$ for a population of 55,000 plants per hectare.

Increases in the production of shoot dry biomass and yield provided by inoculation in this study could be attributed to the stimulus that $A$. brasilense provides to the development of the root system, with increase in density and root hair length and on the volume and number of lateral roots, resulting in greater uptake ability and utilization of water and nutrients like reported by Huergo et al, 2008.

Table 1 - Chemical characterization of the $0-20 \mathrm{~cm}$ layer of soil in the experimental areas

\begin{tabular}{|c|c|c|c|c|c|c|c|c|c|c|}
\hline \multicolumn{11}{|c|}{ Marechal Cândido Rondon -PR Season 2000/2001 } \\
\hline M.O. & $\mathbf{P}$ & $\mathbf{p H}$ & $\mathbf{H}+\mathbf{A l}$ & $\mathbf{A l}^{3+}$ & $\mathbf{K}^{+}$ & $\mathrm{Ca}^{2+}$ & $\mathbf{M g}^{2+}$ & SB & СTC & \multirow[t]{2}{*}{$\mathbf{V}$} \\
\hline $\mathrm{g} \mathrm{dm}^{-3}$ & $\mathrm{mg} \mathrm{dm}^{-3}$ & $\overline{\mathrm{CaCl}_{2}}$ & 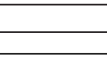 & 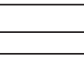 & 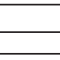 & $\mathrm{cmol}_{\mathrm{c}} \mathrm{dm}$ & 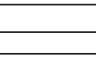 & 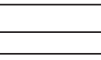 & $\%$ & \\
\hline 29.48 & 4.32 & 5.16 & 4.96 & 0 & 0.7 & 5.7 & 1.33 & 7.71 & 12.7 & 60.85 \\
\hline \multicolumn{11}{|c|}{ Cascavel - PR Season 2002/2003 } \\
\hline M.O. & $\mathbf{P}$ & pH & $\mathbf{H}+\mathbf{A l}$ & $\mathbf{A l}^{3+}$ & $\mathbf{K}^{+}$ & $\mathbf{C a}^{2+}$ & $\mathbf{M g}^{2+}$ & SB & СTC & \multirow{2}{*}{ V } \\
\hline $\mathrm{g} \mathrm{dm}^{-3}$ & $\mathrm{mg} \mathrm{dm}^{-3}$ & $\mathrm{CaCl}_{2}$ & 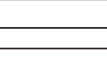 & - & 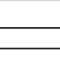 & $\mathrm{cmol}_{\mathrm{c}} \mathrm{dm}$ & & & $\%$ & \\
\hline 36.86 & 4.22 & 5.07 & 5.76 & 0 & 0.6 & 6.3 & 2.3 & 9.10 & 14.9 & 61.24 \\
\hline
\end{tabular}


In the early studies on the associations between plants and Azospirillum spp., researchers believed that the benefits were derived only from biological nitrogen fixation (Dobbelaere et al., 2001). However, later studies demonstrated that the positive effects provided by these nitrogen-fixing micro-organisms are due primarily to morphological and physiological changes in the roots of inoculated plants (Okon \& Vanderleyden, 1997). Such changes in the root system are related to the production of growth enhancing substances by bacteria, since plant growth regulators (phytohormones), mainly the indole acetic acid (IAA), excreted by Azospirillum spp. play an important role in fostering the growth of plants in general (Bashan \& Holguin, 1997).

Regarding the unfolding of the interaction between nitrogen fertilization in sowing and in topdressing for shoot dry biomass (Table 4) for Marechal Cândido Rondon, it can be observed that the use of nitrogen topdressing fertilization provided a higher production of dry biomass in the absence of nitrogen in sowing. This finding may be associated with the soil management system adopted in this cultivation (conventional), which results in lower demand for nitrogen in the early stages of culture, unlike the no-tillage system, in which the high $\mathrm{C}$ / $\mathrm{N}$ ratio of previous culture residues may reduce nitrogen availability due to the immobilization of nitrogen in the soil (Pauletti, 1998).

For the experiment carried out in Cascavel, there was significant interaction among inoculation, $\mathrm{N}$ application at sowing and in topdressing for the variables yield, shoot dry biomass and leaf N content (Table 2). Results for such interactions are shown in Table 5.

Table 2 - Analysis of the variance of yield, shoot dry biomass, plant height, ear insertion height, and nitrogen content in the leaf tissue as a function of inoculation, nitrogen application at sowing and in topdressing

\begin{tabular}{|c|c|c|c|c|c|}
\hline \multicolumn{6}{|c|}{ Marechal Cândido Rondon - PR Season 2000/2001 } \\
\hline & Yield & Biomass & $\begin{array}{c}\text { Ear insertion } \\
\text { height }\end{array}$ & Plant height & Leaf $N$ content \\
\hline Inoc & 1059604.0 & 108112.5 & 0.0017 & 0.0001 & 0.0149 \\
\hline NB & 204000.7 & 1128.13 & 0.0000 & 0.0001 & 0.0149 \\
\hline NC & $3389757.0 * *$ & 899140.50 & 0.0058 & 0.0001 & 0.1365 \\
\hline Inoc*NC & $2229744.0 * *$ & $2298368.00 * *$ & 0.0026 & 0.0024 & 0.0149 \\
\hline Inoc*NB & 339694.0 & 392055.13 & 0.0003 & 0.0008 & 0.0000 \\
\hline $\mathrm{NC} * \mathrm{NB}$ & 686499.0 & $2527876.13^{* *}$ & 0.0048 & 0.0040 & 0.0158 \\
\hline Inoc*NC*NB & 226296.2 & 299925.13 & 0.0053 & 0.0120 & 0.0000 \\
\hline \multicolumn{6}{|c|}{ Cascavel - PR Season 2002/2003 } \\
\hline & Yield & Biomass & $\begin{array}{c}\text { Ear insertion } \\
\text { height }\end{array}$ & Plant height & Leaf $N$ content \\
\hline Inoc & 217571.4 & 482407.53 & 0.0000 & 0.0205 & 0.0052 \\
\hline NB & $3233528.0 * *$ & $10027361.53 * *$ & 0.0205 & 0.0000 & 0.0553 \\
\hline NC & $6575322.1 * *$ & $15996582.03 * *$ & 0.2574 & 0.0048 & 0.0124 \\
\hline Inoc*NC & $2213800.2^{* *}$ & 432682.53 & 0.0790 & 0.0011 & $0.3382 * *$ \\
\hline Inoc*NB & $887079.5^{* *}$ & $5127202.53 * *$ & 0.0081 & 0.0000 & $0.0979 * *$ \\
\hline $\mathrm{NC} * \mathrm{NB}$ & 63750.3 & $1604288.28 * *$ & 0.0052 & 0.0030 & $1.5269 * *$ \\
\hline Inoc*NC*NB & $772547.0^{* *}$ & $1766730.03 * *$ & 0.0443 & 0.0132 & $0.4027 * *$ \\
\hline
\end{tabular}

** Significant by $\mathrm{F}$ test to $1 \%$ probability.

Inoc - inoculation with A. brasilense; NB - nitrogen base; NC - nitrogen fertilization in topdressing..

Table 3 - Shoot dry biomass and maize yield as a function of inoculation and application of nitrogen in topdressing

\begin{tabular}{|c|c|c|c|c|c|c|}
\hline & - Inoc & + Inoc & Mean & - Inoc & + Inoc & Mean \\
\hline & \multicolumn{3}{|c|}{ Shoot dry biomass } & \multicolumn{3}{|c|}{ Yield } \\
\hline & \multicolumn{6}{|c|}{$\mathrm{kg} \mathrm{ha}^{-1}$} \\
\hline $\mathrm{NC}_{0}$ & $9011.0 \mathrm{Bb}$ & $9663.3 \mathrm{Aa}$ & 9337.2 & $5770.4 \mathrm{Bb}$ & $6662.3 \mathrm{Aa}$ & 6216.4 \\
\hline $\mathrm{NC}_{100}$ & 9882.3 Aa & $9462.5 \mathrm{Aa}$ & 9672.4 & 6956.0 Аа & 6785.3 Аа & 6870.6 \\
\hline Mean & 9446.6 & 9562.9 & & 6363.2 & 6723.8 & \\
\hline
\end{tabular}

Means followed by same capital letter in the column, and regular letter on the row do not differ among themselves by Tukey test at $5 \%$. - INOC, + INOC - abscence and presence of inoculant; $\mathrm{NC}_{0}, \mathrm{NC}_{100}$ - doses of nitrogen topdressing fertilization. 
As for productivity, it can be noted that, when inoculation with Azospirillum spp. was performed, there was no significant difference between applying or not nitrogen at sowing (Table 5), which indicates that in the absence of nitrogen at sowing, the practice of seed inoculation can come to meet part of the nitrogen demand in the initial stage of culture. Quadros (2009), in an experiment under tillage with the intent to assess the inoculation of maize genotypes with Azospirillum spp. associated with nitrogen fertilization, has also reported that inoculation can supply part of the nitrogen needed for culture, since inoculation along with the addition of $50 \mathrm{~kg} \mathrm{ha}^{-1}$ of $\mathrm{N}$ in the base, provided grain yield equivalent to the application of $130 \mathrm{~kg} \mathrm{ha}-1$ of $\mathrm{N}$ (50 kg $\mathrm{ha}^{-1}$ at the base and $80 \mathrm{~kg} \mathrm{ha}^{-1}$ in topdressing). Dalla Santa et al. (2008), when working with wheat, also found that the isolated use of inoculation with Azospirillum spp. resulted in increased grain yield of $23.9 \%$ compared to control.

It is observed that in the absence of nitrogen application in sowing the inoculation of Azospirillum spp. gave a mean yield of $7262.5 \mathrm{~kg} \mathrm{ha}^{-1}$, and where there was no inoculation, $6764.6 \mathrm{~kg} \mathrm{ha}^{-1}$ (Table 5 ), reaching, therefore, significant increase in productivity, of about $7.4 \%$, when inoculation was used alone, once again

Table 4 - Shoot dry biomass of maize plants as a function of nitrogen application at sowing and in topdressing

\begin{tabular}{llll}
\hline & NB $_{\mathbf{0}}$ & \multicolumn{1}{c}{$\mathbf{N B}_{\mathbf{2 0}}$} & Mean \\
\cline { 2 - 4 } & \multicolumn{3}{c}{ Shoot dry biomass } \\
\hline \multicolumn{4}{c}{$\mathrm{kg} \mathrm{ha}^{-1}$} \\
\hline $\mathrm{NC}_{0}$ & $9062.0 \mathrm{Bb}$ & $9612.3 \mathrm{Aa}$ & 9337.2 \\
$\mathrm{NC}_{100}$ & $9959.4 \mathrm{Aa}$ & $9385.4 \mathrm{Ab}$ & 9672.4 \\
Mean & 9510.7 & 9498.8 & \\
\hline
\end{tabular}

Means followed by same capital letter in the column, and regular letter on the row do not differ among themselves by Tukey test at $5 \%$.

$\mathrm{NB}_{0}, \mathrm{NB}_{20}$ - doses of nitrogen sowing fertilization; $\mathrm{NC}_{0} \mathrm{NC}_{100}$ - doses of nitrogen topdressing fertilization. confirming the beneficial effects of diazotroph bacteria inoculation to maize crop. Despite this increase in relation to control, the yield values obtained in this experiment are inferior to $8319 \mathrm{~kg} \mathrm{ha}^{-1}$ estimated for the hybrid AG 6018 YG for a population of 55 to 60 thousand plants per hectare.

Nitrogen topdressing fertilization, associated with inoculation, has reduced productivity and shoot dry biomass production (Table 5). These results agree with those obtained by Quadros (2009), on the other hand, Barros Neto (2008) found that the variation of the amount of nitrogen applied in topdressing (100 kg ha-1 and $150 \mathrm{~kg}$ $\mathrm{ha}^{-1}$ ) had no effect on maize yield, whose seeds were inoculated with pre-commercial product based on Azospirillum brasilense.

In this case, it is possible to consider that the incorporation of higher amount of nitrogen fertilizer to soil, due to topdressing fertilization, has undermined the effect of inoculation. According to Hartmann (1988), the efficiency of biological fixation in Azospirillum spp. is rapidly reduced or even inhibited in the presence of higher concentrations of nitrogen compounds in the soil, especially ammonium, which causes the rapid inhibition of nitrogenase activity in bacteria, responsible for the conversion of the atmosphere nitrogen $\left(\mathrm{N}_{2}\right)$ to a form that is acceptable by the plants (Lopes, 2007). This process of control and regulation of nitrogenase complex activity by modulator environmental factors (concentration of assimilated nitrogen and oxygen) becomes necessary due to the high demand for energy involved in the process of reducing atmospheric nitrogen $\left(\mathrm{N}_{2}\right)$ by diazotrophic organisms, some $28 \mathrm{mo}-$ les of ATP per mole of ammonia produced (Baldani et al., 2009).

Positive effect of inoculation was obtained in the absence of nitrogen in topdressing, with a higher production of shoot dry biomass and productivity in relation to treatment without inoculation. However,

Table 5 - Yield, shoot dry biomass and leaf $\mathrm{N}$ content of maize plants as a function of inoculation and nitrogen application at sowing and topdressing - Cascavel

\begin{tabular}{|c|c|c|c|c|c|c|c|c|c|}
\hline & - Inoc & + Inoc & Mean & - Inoc & + Inoc & Mean & - Inoc & + Inoc & Mean \\
\hline & \multicolumn{6}{|c|}{ YieldShoot dry biomass } & \multicolumn{3}{|c|}{ N content } \\
\hline & \multicolumn{6}{|c|}{$\longrightarrow \mathrm{kg} \mathrm{ha}^{-1} \longrightarrow$} & \multicolumn{3}{|c|}{ dag kg-1 } \\
\hline $\mathrm{NB}_{0}$ & $6764.6 \mathrm{Bb}$ & $7262.5 \mathrm{Aa}$ & 7013.6 & $9710.4 \mathrm{Ba}$ & $9697.2 \mathrm{Bb}$ & 9703.8 & $2.07 \mathrm{Bb}$ & $2.24 \mathrm{Aa}$ & 2.16 \\
\hline $\mathrm{NB}_{20}$ & $7733.3 \mathrm{Aa}$ & $7565.3 \mathrm{Aa}$ & 7649.3 & $11062.4 \mathrm{Aa}$ & $10584.9 \mathrm{Ab}$ & 10823.6 & $2.34 \mathrm{Aa}$ & $2.11 \mathrm{Ba}$ & 2.22 \\
\hline Mean & 7249.0 & 7413.9 & & 10386.4 & 10141.0 & & 2.20 & 2.18 & \\
\hline $\mathrm{NC}_{0}$ & $6532.6 \mathrm{Bb}$ & $7223.6 \mathrm{Ba}$ & 6878.1 & $9279.1 \mathrm{Bb}$ & $9834.1 \mathrm{Ba}$ & 9556.6 & 2.16 Аа & $2.25 \mathrm{Aa}$ & 2.20 \\
\hline $\mathrm{NC}_{100}$ & 7965.3 Аа & $7604.7 \mathrm{Ab}$ & 7785.0 & 11493.7 Аа & 10447.6 Ab & 10970.6 & $2.24 \mathrm{Aa}$ & $2.10 \mathrm{Ba}$ & 2.17 \\
\hline Mean & 7249.0 & 7414.2 & & 10386.4 & 10140.8 & & 2.20 & 2.18 & \\
\hline
\end{tabular}

Means followed by same capital letter in the column, and regular letter on the row do not differ among themselves by Tukey test at 5\%. Caption: signs - INOC, + INOC represent the absence and presence of inoculation, $\mathrm{NB}_{0}, \mathrm{NB}_{20}$ represent nitrogen sowing fertilization doses, $\mathrm{NC}_{0}, \mathrm{NC}_{100}$ represent nitrogen topdressing fertilization doses. 
positive responses are not always obtained of increased production as a function of seed inoculation with Azospirillum spp., as reported by Campos et al. (1999) for wheat and oat crops and Campos et al. (2000) for maize. By the other hand, it is agreed that plant genotype is the key factor to obtain the benefits derived from biological nitrogen fixation, combined with the selection of efficient strains.

The application of nitrogen, in topdressing or sowing, has positively influenced shoot dry biomass, as well as productivity, and base nitrogen fertilization has also provided an increase in leaf $\mathrm{N}$ content of plants (Table 5). These results highlight the significant effects of nitrogen on the development of maize crop, because nitrogen provides a significant increase in leaf area and in the production of dry matter weight, resulting in greater grain yield (Escosteguy et al., 1997).

Increased leaf $\mathrm{N}$ content, found in this study, may have enhanced the effects of nitrogen in plant development, since the formation of grain in maize culture is closely related to the translocation of sugars (Crawford et al., 1982) and nitrogen (Karlen et al. 1988) of vegetative organs, especially from the leaves, to the grains. Moreover, a higher content of nitrogen in leaves is associated with increased production of pigments and proteins necessary for photosynthesis and photochemical and carboxylate processes performance (Field \& Mooney, 1986; Andreeva et al., 1998), increasing the photosynthetically active leaf area of plant directly associated with crop yield.

On the other hand, the associations between inoculation and nitrogen fertilization, base or topdressing, have caused a reduction in leaf $\mathrm{N}$ content. Machado et al. (1998), have found similarities of leaf N contents, by comparing the isolated use of nitrogen topdressing fertilization (100 $\mathrm{kg} \mathrm{N} \mathrm{ha}^{-1}$ ) in maize in relation to the use associated with the inoculation of diazotrophs.

The contribution of biological nitrogen fixation in grasses or food products, such as maize and wheat, in fertilization programs is an issue that needs further study. Research results are not always positive, as stated by Moreira \& Siqueira (2002), increased yield in response to inoculation are generally about 5 to $30 \%$, however it is not clear whether the expectation is overestimated or not, considering the tendency of not publishing results.

\section{CONCLUSION}

In both seasons, the ear insertion height and total plant height were not affected by the factors under study.

For the season 2000/2001, the increases in the production of shoot dry biomass and grain yield provided by the inoculation were 7.2 and $15.4 \%$, respectively.
For the season 2002/2003, inoculation with Azospirillum spp. caused an increase of $7.4 \%$ in yield, compared with control, without nitrogen at sowing and without inoculation. In addition, nitrogen topdressing fertilization, associated with the use of inoculation, has reduced yield and the shoot dry biomass production.

Nitrogen fertilization at sowing has increased leaf $\mathrm{N}$ content; however, when complemented by inoculation, it caused a reduction of such a variable.

\section{REFERENCES}

Andreeva TT, Maevskaya SN \& Voevudskaya SYU (1998) The relationship between photosynthesis and nitrogen assimilation in mustard plants exposed to elevated nitrate rates in nutrient solutions. Russian Journal of Plant Physiology, 45:702-705.

Baldani JI, Caruso L, Baldani VLD, Goi SR \& Döbereiner J (1997) Recent advances in BNF with non-legume plants. Soil Biology \& Biochemistry, 29:911-922.

Baldani JI, Teixeira KRS, Schwab S, Olivares FL, HEmerly AS, Urquiaga S, Reis VM, Noqueira EM, Araujo JLS, Borges LE, Soares LHB, Vinagre F, Baldani VLD, Carvalho TLG, Alves BJR, James EK, Jantalha CP, Ferreira PCG, Vidal MS \& Boddey RM (2009) Fixação biológica de nitrogênio em plantas da família Poaceae (Antiga Graminae). In: Ribeiro MR, Nascimento CWA do, Filho MRR \& Cantalice JRB (Eds.) Tópicos em Ciência do Solo. Viçosa, Sociedade Brasileira Ciência do Solo. p.203-271.

Barros Neto CR (2008) Efeito do nitrogênio e da inoculação de sementes com Azospirillum brasilense no rendimento de grãos de milho. Monografia de Graduação. Universidade Estadual de Ponta Grossa, Ponta Grossa, 28p.

Bashan Y \& Holguin G (1997) Azospirillum-plant relationships: Environmental and physiological advances (1990-1996). Canadian Journal of Microbiology, 43:103-121.

Campos BH, Theisen S \& Gnatta V (1999) Inoculante "Graminante" nas culturas de trigo e aveia. Ciência Rural, 29:401-407.

Campos BC de \& Gnatta STV (2000) Avaliação do inoculante "Graminante" na cultura do milho. Ciência Rural, 30:713-715.

Cavallet LE, Pessoa AC dos S, Helmich JJ, Helmich PR \& Ost CF (2000) Produtividade do milho em resposta à aplicação de nitrogênio. Revista Brasileira de Engenharia Agrícola e Ambiental, 4:129-132.

Crawford TW, Rendig VV \& Broadbent FE (1982) Sources, fluxes, and sinks of nitrogen during early reproductive growth of maize (Zea mays L.). Plant Physiology, 70:1654-1660.

Dalla Santa OR, Dalla Santa HS, Fernández R, Michelena G, Ronzelli Júnior P \& Soccol CR (2008) Influence of Azospirillum sp. inoculation in wheat, barley and oats. Ambiência, 4:197-207.

Dobbelaere S, Croonenborghs A, Thys A, Ptacek D. Vanderleyden J, Dutto P, Labandera-Gonzalez C, Caballero-Mellado J, Aguirre JF, Kapulnik Y, Brener S, Burdman S, Kadouri D, Sarig S \& Okon, Y (2001) Response of agronomically important crops to inoculation with Azospirillum. Australian Journal of Plant Physiology, 28:871-879.

Döbereiner J (1992) Fixação de nitrogênio em associação com gramíneas. In: Cardoso EJBN, Tsai SM \& Neves MCP (Eds.) Microbiologia do solo. Campinas, SBCS. p.173-180. 
Escosteguy PAV, Rizzardi MA \& Argenta G (1997) Doses e épocas de aplicação de nitrogênio em cobertura na cultura do milho em duas épocas de semeadura. Revista Brasileira de Ciência do Solo, 21:71-77

Field C \& Mooney HA (1986) The photosynthesis nitrogen relationship in wild plants. In: Givnish TJ (Ed.) On the economy of plant form and function. Cambridge, Cambridge University Press. p.25-55.

Hartmann A (1988) Ecophysiological aspects of growth and nitrogen fixation in Azospirillum spp. Plant and Soil, 110:225-238.

Huergo LF, Monteiro RA, Bonatto AC, Rigo LU, Steffens MBR, Cruz LM, Chubatsu LS, Souza EM \& Pedrosa FO (2008) Regulation of nitrogen fixation in Azospirillum brasilense. In: Cassán FD \& Salamone IG de (Eds.) Azospirillum sp.: cell physiology, plant interactions and agronomic research in Argentina. Córdoba, Asociación Argentina de Microbiología. p.17-28.

Hungria M, Campo RJ, Souza EM \& Pedrosa FO (2010) Inoculation with selected strains of Azospirillum brasilense and A. lipoferum improves yields of maize and wheat in Brazil. Plant and Soil, 331:413-425.

Karlen DL, Flanner RL \& Sadler EJ (1988) Aerial accumulation and partitioning of nutrients by corn. Agronomy Journal, 80:232-242.

Lopes AS (2007) Fixação biológica do nitrogênio no sistema soloplanta. In: I Simpósio Sobre Nitrogênio e Enxofre na Agricultura Brasileira, Piracicaba. Anais, IPNI Brasil, p.43-72.

Machado AT, Sodek L, Döbereiner J \& Reis VM (1998) Efeito da adubação nitrogenada e da inoculação com bactérias diazotróficas no comportamento bioquímico da cultivar de milho Nitroflint. Pesquisa Agropecuária Brasileira, 33:961-970.
Malavolta E, Vitti GL \& Oliveira AS (1997) Avaliação do estado nutricional das plantas: princípios e aplicações. $2^{\circ}$ ed. Piracicaba, Potafós. 319p.

Moreira FMS \& Siqueira JO (2002) Microbiologia e bioquímica do solo. Lavras, Universidade Federal de Lavras. 625p.

Okon Y \& Vanderleyden J (1997) Root-associated Azospirillum species can stimulate plants. Applied and Environmental Microbiology, 63:366-370.

Pauletti V (1998) Ureia no milho: quanto e quando aplicar no sistema de plantio direto. Revista Batavo, 80:36-39.

Quadros PD de (2009) Inoculação de Azospirillum spp. em sementes de genótipos de milho cultivados no Rio Grande do Sul. Dissertação de Mestrado. Universidade Federal do Rio Grande do Sul, Porto Alegre, 62p.

Reis Júnior FB, Machado CTT, Machado AT \& Sodek L (2008) Inoculação de Azospirillum amazonense em dois genótipos de milho sob diferentes regimes de nitrogênio. Revista Brasileira de Ciência do Solo, 32:1139-1146.

Taiz L \& Zeiger E (2004) Fisiologia Vegetal. 3a . ed. Porto Alegre, Artmed. 719p.

Tedesco MJ, Gianelo C, Bissani CA, Bohnen H \& Volkweis SJ (1995) Análises de solo, planta e outros materiais. $2^{a}$. ed. Porto Alegre, UFRGS, Departamento de Solos. 174p. (Boletim técnico, 5). 